\title{
コバルト・クロム合金鋳造体の表面あらさに関する研究
}

\author{
野首 孝问 川畑 直嗣 山田 隆司奥野善彦
}

\section{Studies on Surface Roughness of Chromium-Cobalt Castings}

\author{
Takashi Nokubi, Naotsugu Kawahata, Takashi Yamada, Yoshihiko Okuno
}

\section{緒言}

近年, 高温鋳造法の発達にともない,コバルト・クロ 么合金を使用した鋳造床が広く臨床で用いられるように なった.この種の合金は機械的性質がすぐれ，化学的に も安定であり，また比重が金合金の約 $1 / 2$ であり，さら に生体組織に対する親和性にもすぐれているなどの多く の特徴 ${ }^{1 ~ 3)}$ を有している. また, この合金の熔融温度は $1,300 \sim 1,500^{\circ} \mathrm{C}$ と高いため, その鋳造には高温鋳造用 埋没材が必要であり, リン酸塩系埋没材, エチルシリケ 一ト系埋没材，コロイダルシリカ系埋没材，石亮系埋没 材などが用いられている. この中でリン酸塩系埋没材 は，すぐれた耐熱性を有し，保存性にもすぐれ，使用法 が簡便であり，さらに圧縮強度が大きく模型が強固であ るなどの利点を有しているため, 現在最む多く使用され ている.しかし，この種の埋没鋳造材は, 時にコバルト・ クロム合金と反応して緑色の反応生成物を形成し, 鋳造 体表面が粗䊁になるという欠点が指摘されている4,5).こ のような鋳造体の表面あらさは, 各種補綴物の適合性に 対して大きな影響を及ぼすのみならず，睢蝕の発生ある いは粘膜の炎症などにも影響するものと考えられる.し かし，これまで中熔合金の鋳造体における表面あらさに 関しては，種々の報告がみられる 造体の表面あらさに関する研究は少なく, とくにサンド ブラスト処理, 電解研磨処理が鋳造体の表面あらさに及 ぼす影響について検討したものは，ほとんどみられな '.

そこで本研究は，コバルト・クロム合金による鋳造床 の粘膜面や鋳造鈎の内面を想定し，その製作過程におけ

大阪大学歯学部歯科補緅学第 2 講座（主任：河合庄治郎教 授)

The 2nd Department of Prosthetic Dentistry, Osaka University Dental School (Chief : Prof. Shojiro Kawai) 昭和 53 年 7 月 22 日受付
る各種操作が，鋳造体の表面あらさに及ぼす影響を知る ために行ったものである. まず，触針式あらさ測定機を 用いて, 鋳造, サンドブラスト処理, 電解研磨処理など の各種操作後に扔りる表面あらさを測定し, さらに走査 型電子顕微鏡を用いてその表面性状を詳細に観察し, ま た各種操作時における鋳造体の厚さの変化などについて も測定を行い,これらを比較検討した結果, いくつかの 知見を得たので報告する.

\section{実験材料ならびに方法}

\section{1. 試料の製作}

まず，寒天印象材（大成社製，タイゲル）を用いて平 滑なガラス面を印象し, その印象面にリン酸塩系埋没材 （松風社製，ハイベスト $\mathrm{D}$, 混液比 : 0.14）を注入して 埋没材模型板（厚さ: $2 \mathrm{~mm}$ ) を製作した. なお, 対照 として同じ平滑なガラス板上に直接埋没材を注入して, 同様の模型板を製作した.

次いで,この 2 種類の埋没材模型板上に, 綐 $30 \mathrm{~mm}$, 横 $20 \mathrm{~mm}$, 厚さ $0.7 \mathrm{~mm}$ のワックスパターンを製作し た後, このパターンの長軸方向に平行となるように直径 $2.5 \mathrm{~mm}$ のスプルーを植立した（図 1，2）.これを水中

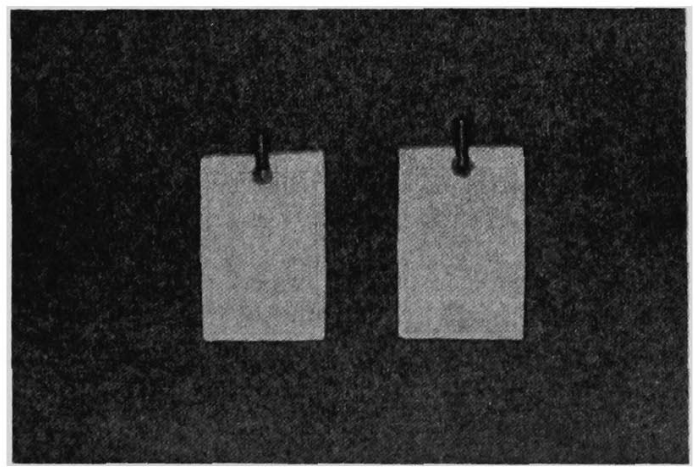

図 1 ワックスパターンの圧接とスプルー付着 


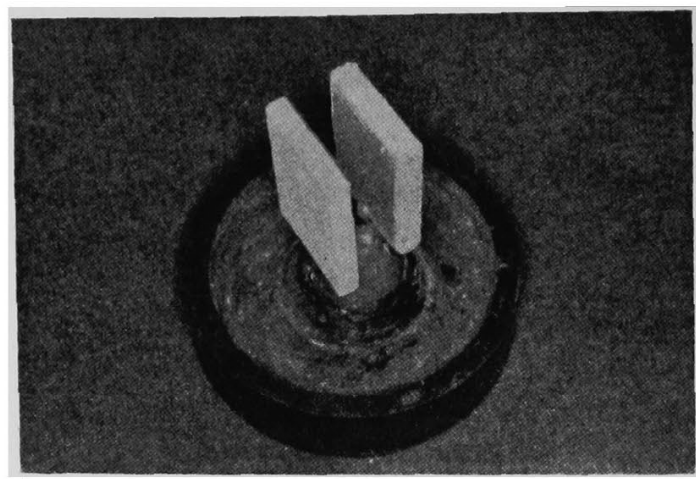

図 2 ワックスパターンの埋没方向

に 3 分間浸漬した後, 同一埋没材（混水比：0.14）を用 いてリングレス埋没を行った. なお，本実験では，埋没 材模型板のワックスコーティングは行わなかった。

埋没 24 時間経過後, 鋳型を室温から $800^{\circ} \mathrm{C}$ まで 4 時 間で上昇させ, さらに $800^{\circ} \mathrm{C}$ で 1 時間倸留した後, ア ルゴンアーク加圧鋳造機（松風社製，アルゴンキャスタ 一）を用いて鋳造を行った. 使用金属は，コバルト・ク ロム合金の 1 種であるスマロイコバルト（松風社製）と した. 鋳造後, リングを室温まで放冷し, 注意深く鋳造 体を取り出した. 次に，鋳造体に付着した埋没材およぴ 酸化膜を除去するため，鋳造体を $50 \% \mathrm{NaOH}$ 沸騰溶液 中に 30 分間浸漬し，次いで沸滕水中に 5 分間浸漬した. 後, さらに, 水中で 10 分間超音波洗浄を行い, 測定試 料とした。 なお，寒天印象を行って製作した鋳造体試料 (実験群) とガラス面上に埋没材を注入して製作した鋳 造体試料 (対照群) の試料数はそれぞれ 12 個ずつとし た.

次に，サンドブラスト処理の影響を検討するために， 各試料群をさらに 2 群（各6 個）に分けて，小型サンド ブラスト（大栄歯科産業社製，サンドブラストE型）と 大型サンドブラスト（厚地鉄鋼社製，キャビネットタイ プ B-1 型)で処理を行った. 小型サンドブラスト処理 では空気圧を $4 \mathrm{~kg} / \mathrm{cm}^{2}$ とし，各試料をノズル先端より $5 \mathrm{~cm}$ の位置で保持して 1 分間処理を行い，各種の測定 や観察を行った後，さらに 2 分間処理を行い， 3 分間処 理の試料とした. 一方, 大型サンドブラスト処理では, 空気圧を $4 \mathrm{~kg} / \mathrm{cm}^{2}$ とし, 各試料をノズルの先端より $10 \mathrm{~cm}$ の位置で保持して 15 秒間処理を行った。

次に，埋没材模型面に接した鋳造体試料の被検面のみ が電解研磨されるようにその裏面をコーティングし，被 検面をエチルアルコールで脱脂した後, 電解研磨器 (松 風社製) の使用電流を $4 \mathrm{~A}$ として 1 分間電解研磨を行

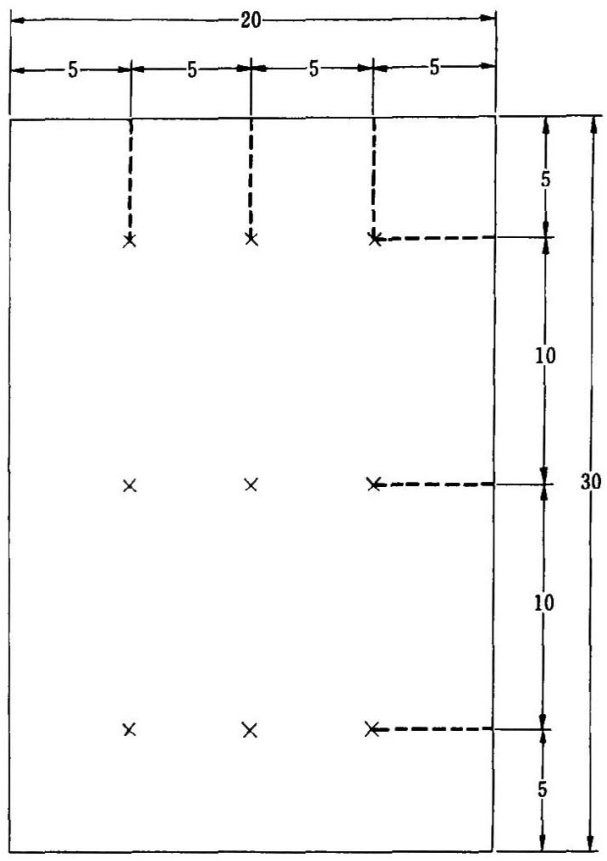

図 3 鋳造体試料における厚さの計測部位 (単位 : mm)

った．測定ならびに観察の後，さらに 2 分間電解研磨を 行い, 3 分間処理の試料とした. なお, 電解研磨液の温 度は $15 \sim 30^{\circ} \mathrm{C}$ の範囲内とした。

\section{2. 表面あらさの測定}

被検面のスプルー付着部に近い $1 / 2$ の部分（以下スプ ルー近接部とする）と離れた $1 / 2$ の部分（以下スプルー 遠隔部とする）において，測定部位をそれぞれ 5 カ所ず つ選択し，小坂式 SE-4 型あらさ測定機を用いて，各処 理前後における表面あらさの測定を行った. 測定条件 は, 測定距離 $5 \mathrm{~mm}$, 縦倍率 1,000 倍, 横倍率 100 倍と し, 表面あらさの表示には中心線平均あらさ $\left(\mathrm{R}_{\mathrm{a}}\right)$ と最 大あらさ $\left(\mathbf{R}_{\max }\right)$ を用いた。

\section{3、鋳造体試料の厚さの变化の測定}

鋳造体試料のサンドブラスト処理および電解研磨処理 による厚さの変化を知るために，図 3 に示したように 9 カ所の測定部位を設定し, 各処理前後における厚さを 1/1,000 mm 精度のマイクロメーター（三豊社製）を用 いて測定した. なお，その平均值の小数点以下第 1 位を 四捨五入した値をその試料の厚さとした. 


\section{4. 走查型電子顕微鏡に上る観察}

各試料の処理前後における表面性状を詳細に観察する ために，導電性樹脂（藤倉化成社製，ドータイト）を用 いて各試料を試料台に固定した後, EIKO イオンコータ 一 IB-3 (エイコー社製)を用いて試料表面に金蒸着を 行い, 走査型電子顕微鏡（日立明石社製, MINISEM-4T 型）により， 2 次電子線像の観察を行った。 なお，倍率 は 100 倍と 1,000 倍の 2 種とした.

\section{実験結果}

\section{1、鋳造直後の表面あらさ}

鋳造直後の鋳造体試料の中心線平均あらさおよび最大 あらさの測定結果は，図 4, 表 1 に示すとおりである.

中心線平均あらさにおいて，対照群ではスプルー近接 部が約 $2.4 \mu$, スプルー遠隔部が約 $2.0 \mu$ を示し, 測定 部位による差が認められた。 また，実験群ではスプルー 近接部が約 $3.5 \mu$, スプルー遠隔部が約 $3.3 \mu$ を示し, 測定部位による差はほとんどみられなかった。

一方, 最大あらさにおいて, 対照群, 実験群ともに, スプルー近接部と遠隔部との間に有意差は認められず, 対照群で約 $7.8 \mu$, 実験群で約 $11.3 \mu$ を示した.

次に, 対照群と実験群との間には, 中心線平均あらさ および最大あらさともに明らかに差が認められ，実験群 の方が大きい値を示した.

2. サンドブラスト処理後の表面あらさ

1）小型サンドブラスト処理後の表面あらさ
小型サンドブラストで 1 分間拉よび 3 分間処理した鋳 造体試料の表面あらさの測定結果は，図 4 ，表 1 に示す とおりである. なお，サンドブラスト処理後の表面あら さにおいて，スプルー近接部と遠隔部との間に有意の差 が認められなくなったので，以後各試料における 10 力 所の測定值を平均してその試料のあらさ值とした。

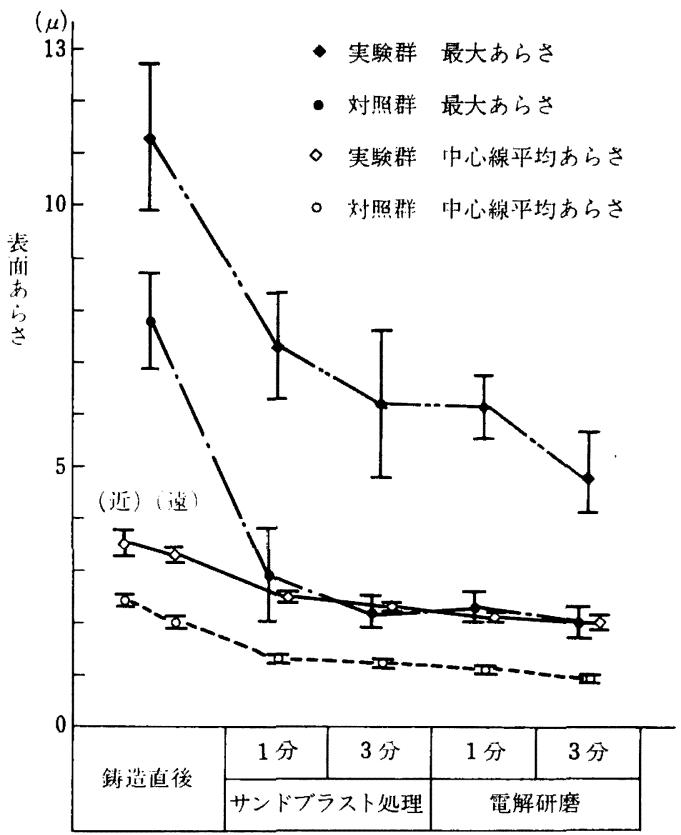

図 4 小型サンドブラスト処理え電解研磨による表面 あらさの変化

表 1 各種研磨操作による中心線平均あらさ $\left(\mathrm{R}_{\mathrm{a}}\right)$ と最大あらさ $\left(\mathrm{R}_{\max }\right)$

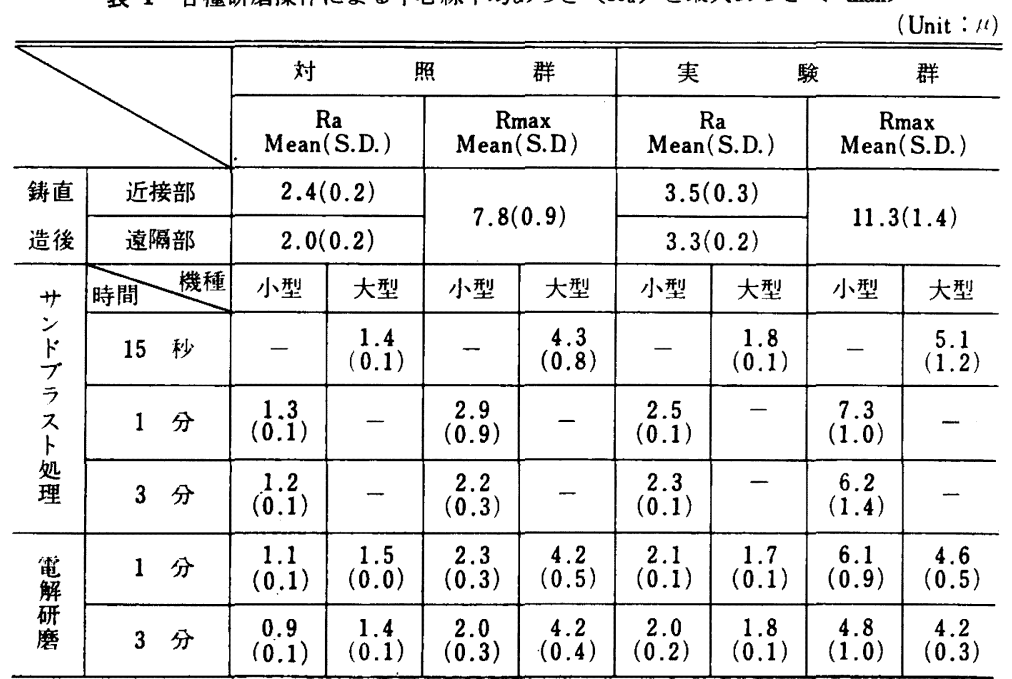


1 分間処理後の中心線平均あらさは, 対照群で約 1.3 $\mu$, 実験群で約 $2.5 \mu$ となり, それぞれ鋳造直後より約 $1 \mu$ 小さくなった. また, 1 分間処理後の最大あらさは, 対照群で約 $2.9 \mu$, 実験群で約 $7.3 \mu$ となり, 鋳造直後 よりそれぞれ約 $4.9 \mu$, 約 $4 \mu$ 小さくなり，いずれの場 合でも実験群の方が対照群よりも明らかに大きな值を示 した.

3 分間処理後における中心線平均あらさと最大あらさ は, 対照群, 実験群ともに 1 分間処理後の値よりもわず かに小さくなる傾向を示したが，いずれも有意の差は認 められなかった。 また, 対照群と実験群とを比較すると， 1 分間処理後と同様に明らかに差が認められ, 実験群の 方が中心線平均あらさで約 $1 \mu$, 最大あらさで約 $4 \mu$ 大 きい值を示した.

\section{2）大型サンドブラスト処理後の表面あらさ}

大型サンドブラストで 15 秒間処理した鋳造体の表面 あらさの測定結果は, 図 5 , 表 1 に示すとおりである.

中心線平均あらさは, 対照群で約 $1.4 \mu$ となり, 鋳造 直後より約 $1 \mu$ 小さくなったが, 対照群の小型サンドブ ラスト処理の值よりもわずかに大きくなる傾向を示し た. また, 実験群の中心線平均あらさは約 $1.8 \mu$ で, 鋳 造直後より約 $1.5 \mu$ 小さくなり, 実験群の小型サンドブ

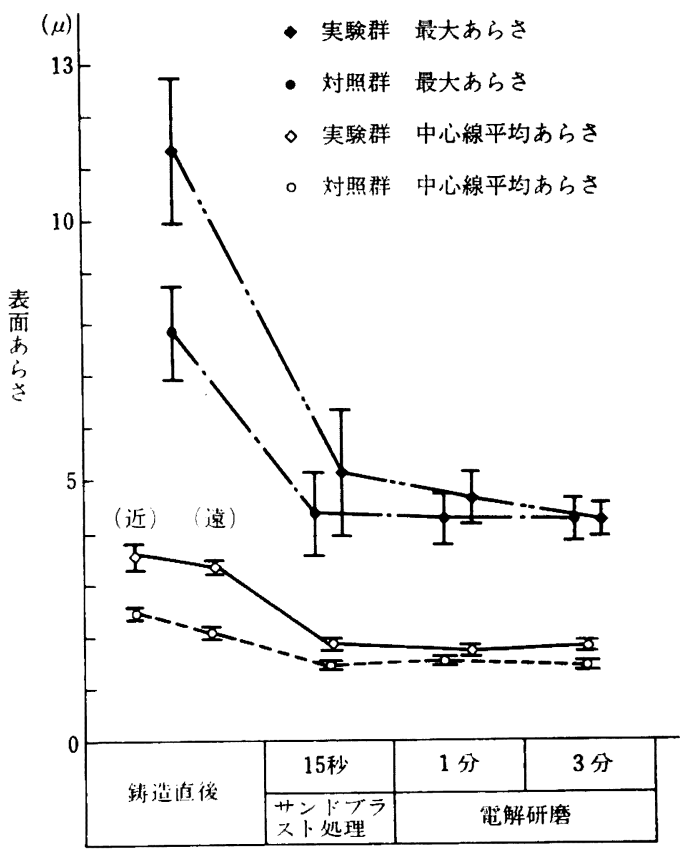

図 5 大型サンドブラスト処理と電解研磨による表面 あらさの変化
ラスト 3 分間処理後の中心線平均あらさより有意に小さ な值を示した．また，実験群の方が対照群よりやや大き な值を示したが，小型サンドブラスト処理の值よりもそ の差は, 明らかに小さくなった。

最大あらさについては, 対照群で約 $4.3 \mu$, 実験群で 約 $5.1 \mu$ となり, 鋳造直後よりそれぞれ約 $3.5 \mu$, 約 $6.2 \mu$ 小さくなった. しかし, この処理時における対照 群と実験群との差は, 鋳造直後よりも小さくなった.

\section{3. 電解研磨処理後の表面あらさ}

電解研磨処理後の鋳造体の表面あらさの測定結果は, 図 4,5, 表 1 に示すとおりである.

中心線平均あらさでは，すべての試料群において，サ ンドブラスト処理後の值と 1 分間電解研磨後の値との間 に有意の差が認められなかった. また， 3 分間電解研磨 後では，小型サンドブラストで処理した対照群と実験群 は，それぞれ約 $0.9 \mu$, 約 $2.0 \mu$ となり，サンドブラス 卜処理後の值より有意に小さくなった. しかし，大型サ ンドブラスト処理を行った試料群では, 電解研磨の処理 時間による影響はほとんど認められなかった。

最大あらさについては，すべての試料群において電解 研磨によるあらさ值の変化は認められず，サンドブラス 卜処理後の值と 3 分間電解研磨後の値との間に有意の差 は認められなかった。

また，対照群と実験群のあらさ值の差は，サンドブラ スト処理後とほとんど同様であった. すなわち，小型サ ンドブラスト処理群では，中心線平均あらさおよび最大 あらさにおいて，明らかに実験群の方が大きい値を示し た. 一方, 大型サンドブラスト処理群では, 中心線平均 あらさでは実験群の方がやや大きくなる傾向を示した が、最大あらさではほとんどその差は認められなかっ た.

\section{4. 鋳造体㷚料の厚さの変化について}

サンドブラスト処理ならびに電解研磨における鋳造体 の厚さの減少量の測定結果は, 図 6, 7, 表 2 に示すとお りである.

小型サンドブラスト処理による鋳造体試料の厚さの減 少量は, 1 分間処理後では対照群, 実験群ともに約 $2 \mu$ となった. さらに， 2 分間処理後では，対照群で約 $4 \mu$, 実験群で約 $3 \mu$ の減少がみられたが，両者に有意の差は 認められなかった。

一方, 大型サンドブラスト処理による厚さの減少量 は, 対照群で約 $11 \mu$, 実験群で約 $12 \mu$ となり，両者に 


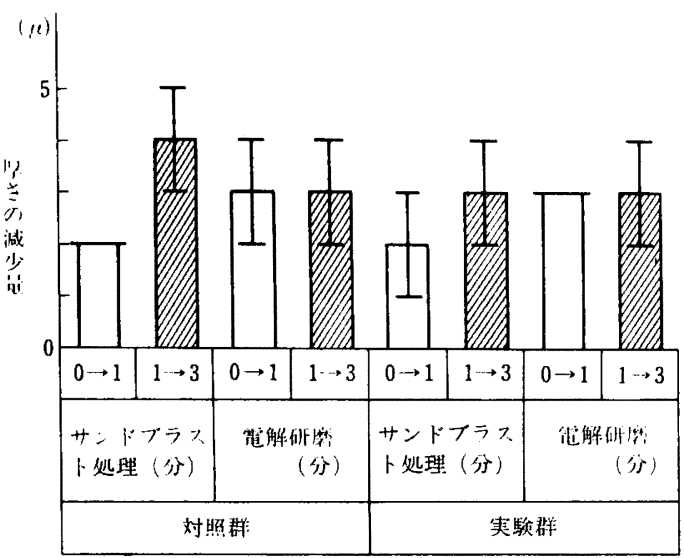

図 6 小型サンドブラスト処理と電解研磨による厚さ の減少量

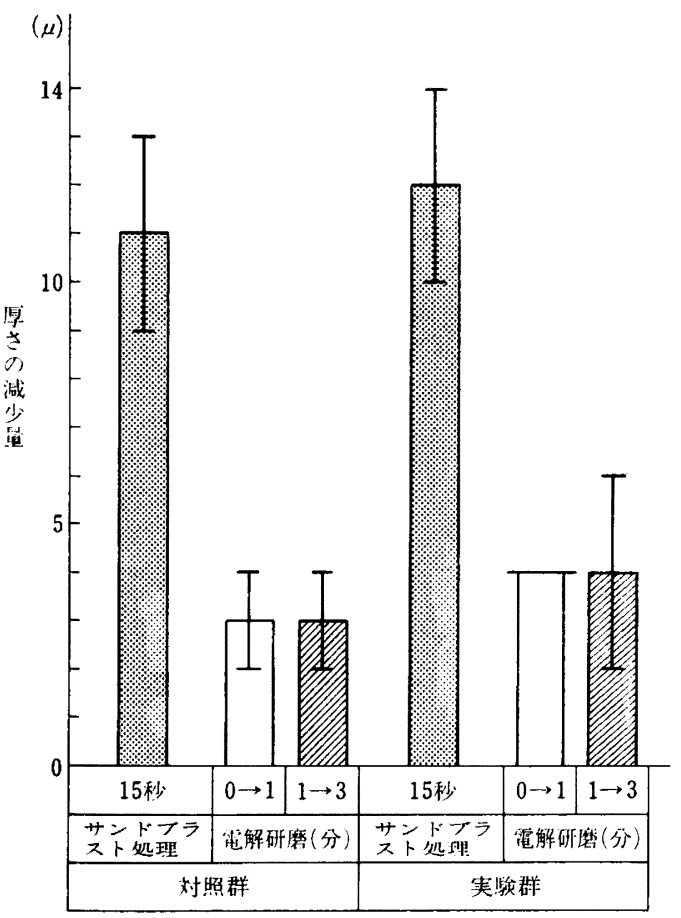

図 7 大型サンドブラスト処理と電解研磨による厚さ の減少昆

有意の差は認められなかった。

また, 1 分間の電解研磨処理による厚さの減少量は, ほとんどの試料群において約 $3 \mu$ を示したが, 大型サン ドブラスト処理を行った実験群では約 $4 \mu$ 減少し，他の 試料群よりもやや大きな值を示した. さらに，2 分間電 解研磨した 3 分後では, 対照群, 実験群ともに 1 分後の
表 2 各種研磨操作による厚さの減少量における平均值 と標準偏差

(Unit : $\mu$ )

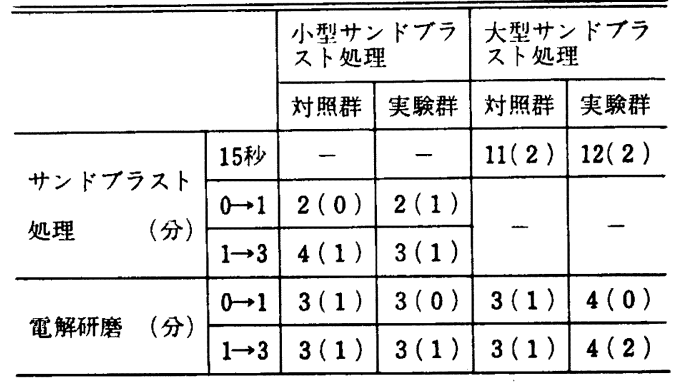

厚さに比べて 3〜4 $\mu$ の厚さの減少がみられ，各試料間 において有意の差はほとんど認められなかった.

\section{5. 走査型電子顕微鏡による 2 次電子線像の観察}

対照群および実験群の鋳造体試料被検面の走查型電子 顕微鏡写真を図 8〜15 に示した.

鋳造直後の鋳造体試料被検面を対照群と実験群とで比 較すると，100 倍拡大像では，対照群（図 8-a）より実 験群（図 8-b）の方がやや粗粘な像を呈していることが 観察される．また，1,000 倍扡大像では，対照群（図 8c）上り実験群（図 8-d）の方が凹凸がやや大きく，個 々の凹部, 凸部の面積も実験群の方が大きいことが観察 される.

小型サンドブラストで 1 分間処理後の鋳造体試料被検 面の状態を比較すると，100 倍抗大像では，対照群（図 9-a）の方が実験群（図 9-b）より均等な像を呈して おり，実験群の方が小孔がより多く認められた.また， 1,000 倍扡大像では，実験群（図 9-d）において大きな 凹部が認められたのに対し, 対照群（図 9-c）では凹部 はやや小さく, 板状構造の像を呈する部分が多く観察さ れた.

さらに，小型サンドブラストで 3 分間処理後の鋳造体 試料被検面を比較すると, 100 倍拡大像では, 対照群（図 10-a） も実験群（図 10-b）も不規則な境界をもつ小 さな板状構造の像を呈しているが，実験群の方に小孔が やや多く認められ，また 1 分間処理後よりも平坦な板状 構造を呈することがより明確となった. 一方，1,000 倍 拡大像では，対照群 (図 10-c) と実験群 (図 10-d) との間で粒子の大きさに著明な差は認められないが，対 照群の方がより平坦な像を呈し, 1 分間処理後の像と比 ベると明らかに凹凹の程度は少なくなった。

大型サンドブラストで 15 秒間処理後の鋳造体試料被 検面を比較すると, 100 倍拡大像では,対照群 (図 11-a), 


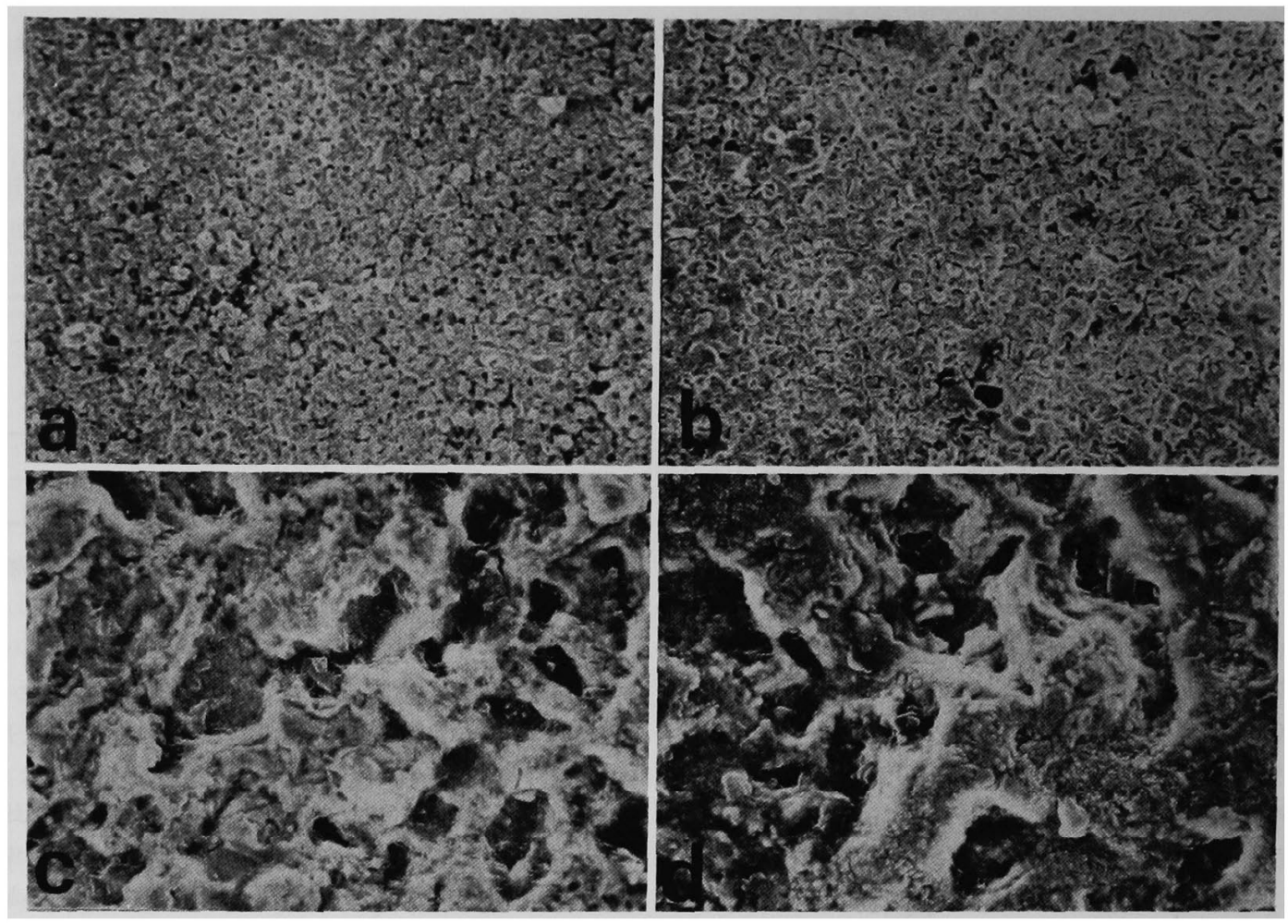

図 8 鋳造直後の走査型電顕写真像

a : 対照群 $(\times 100) \quad$ b : 実験群 $(\times 100) \quad c$ : 対照群 $(\times 1,000) \quad$ d : 実験群 $(\times 1,000)$

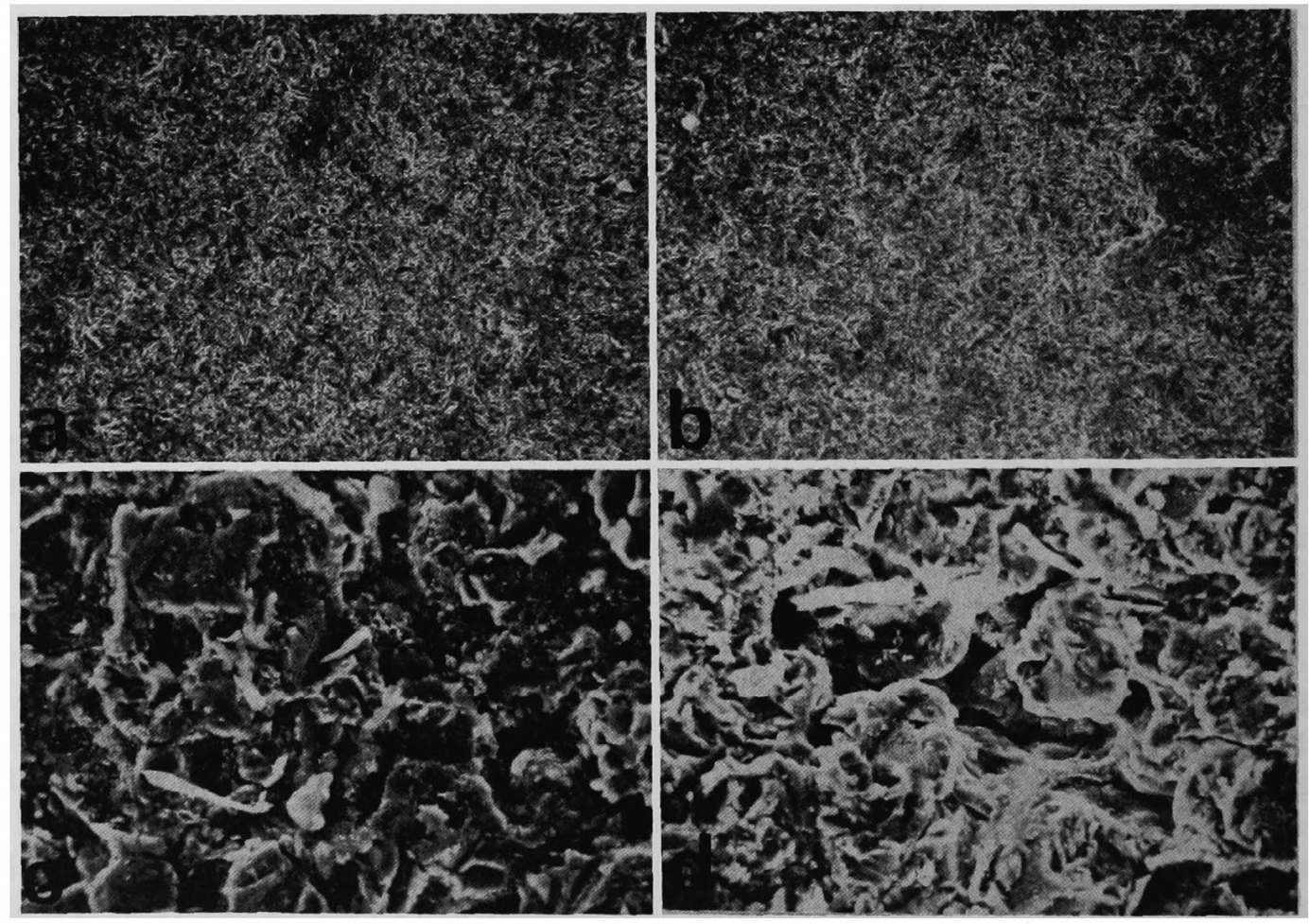

図 9 小型サンドブラスト 1 分間処理後の走査型電顕写真像

$a:$ 対照群 $(\times 100) \quad b$ : 実験群 $(\times 100) \quad c$ : 対照群 $(\times 1,000) \quad d:$ 実験群 $(\times 1,000)$ 


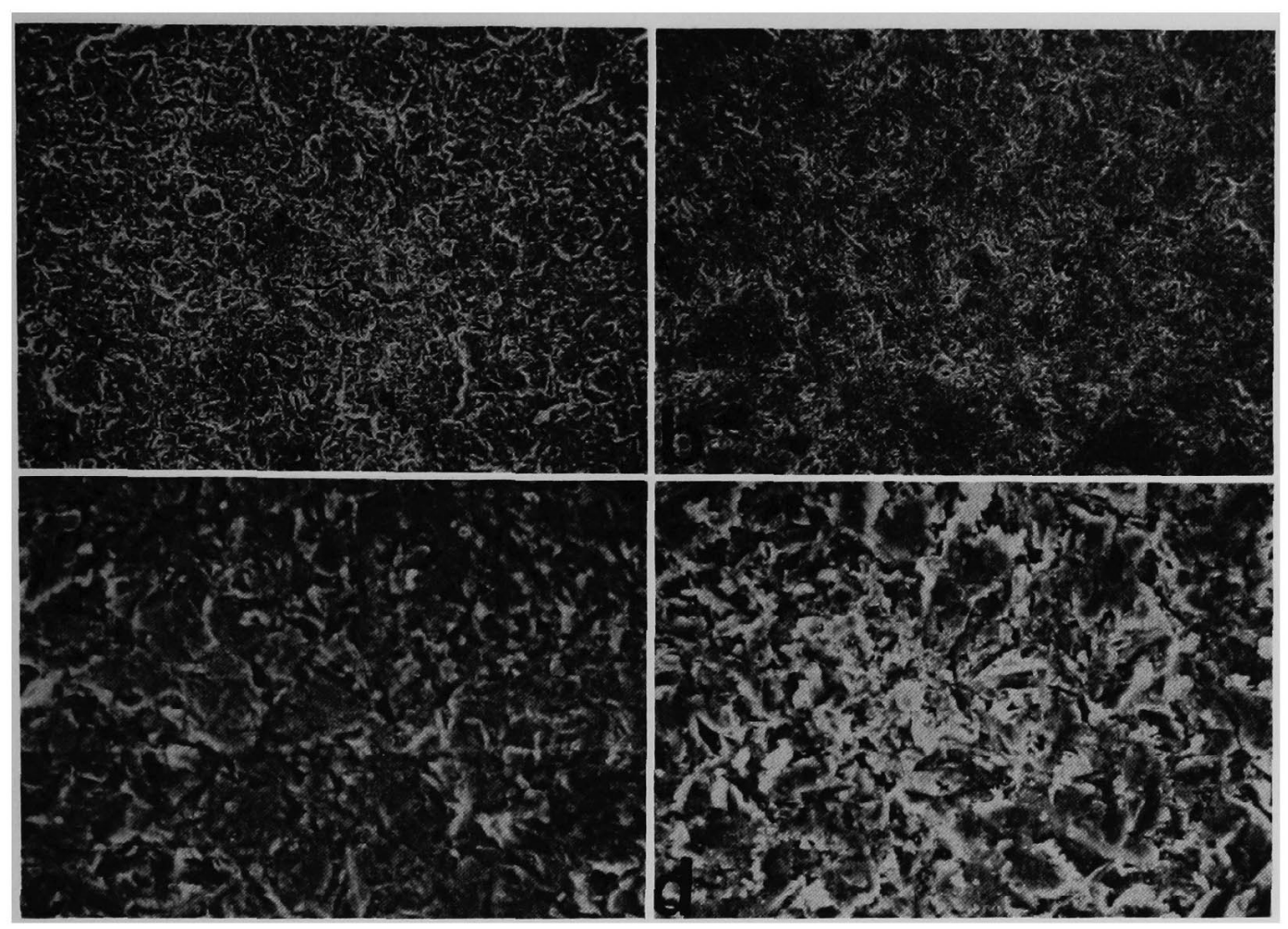

図 10 小型サンドブラスト 3 分間処理後の走査型電顕写真像

a : 対照群 $(\times 100) \quad b$ : 実験群 $(\times 100) \quad c$ : 対照群 $(\times 1,000) \quad d:$ 実験群 $(\times 1,000)$

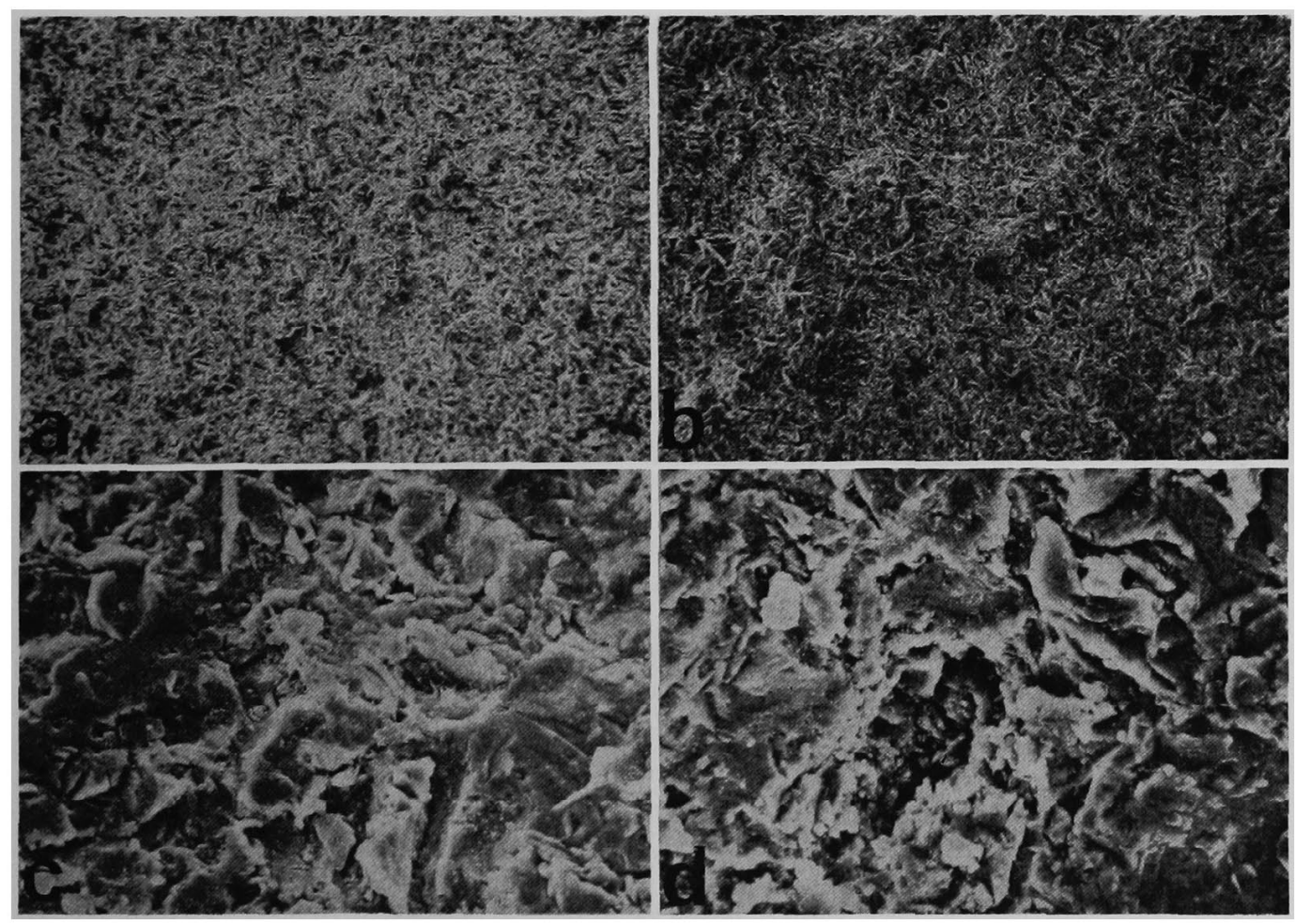

図 11 大型サンドブラスト 15 秒間処理後の走查型電顕写真像

a : 対照群 $(\times 100) \quad$ b : 実駿群 $(\times 100) \quad$ c : 対照群 $(\times 1,000) \quad$ d : 実験群 $(\times 1,000)$ 


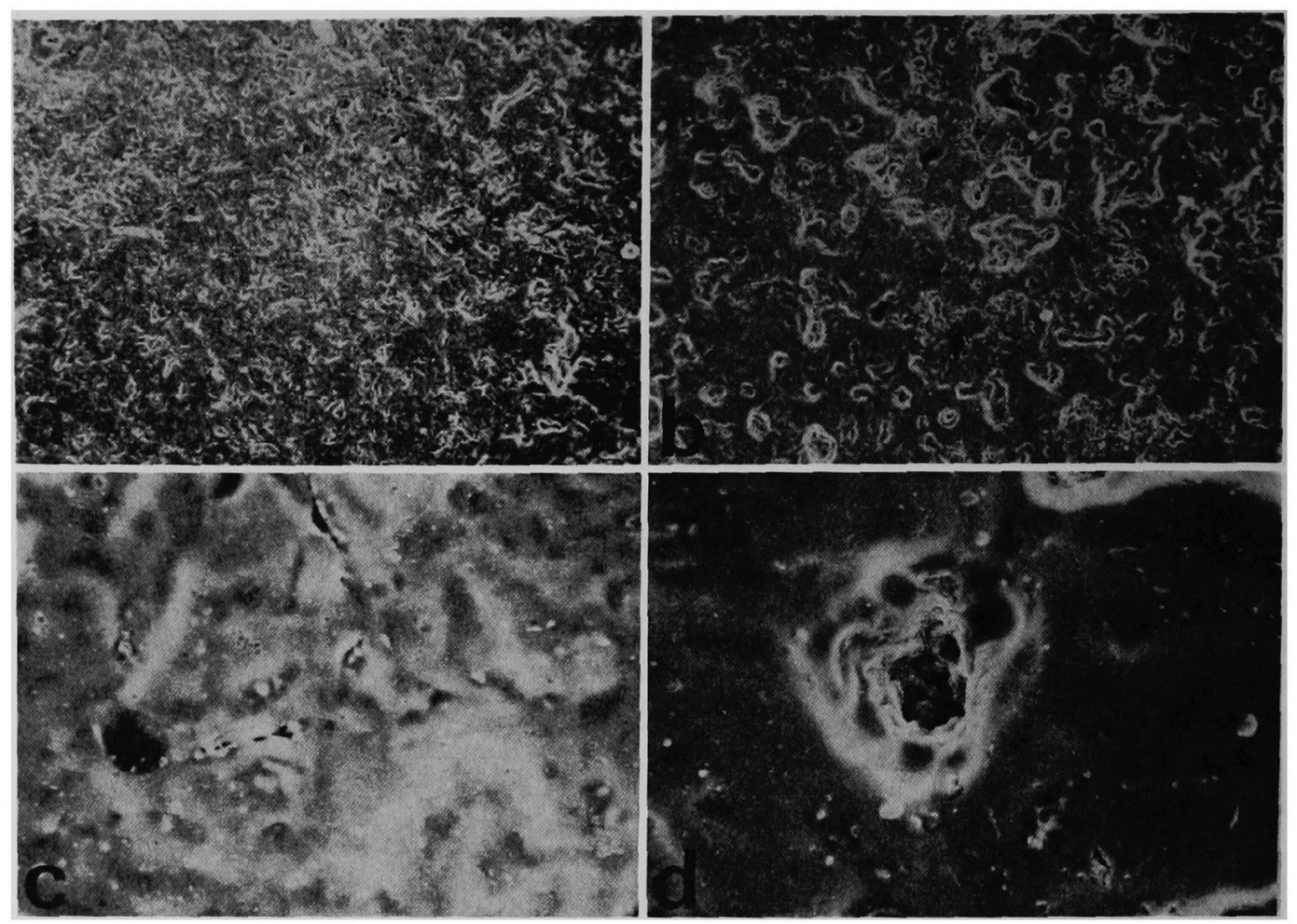

図 12 電解研磨 1 分間処理後の走查型電顕写真像 (小型サンドブラスト処理) a : 対照群 $(\times 100) \quad$ b : 実験群 $(\times 100) \quad c$ : 対照群 $(\times 1,000) \quad d:$ 実験群 $(\times 1,000)$

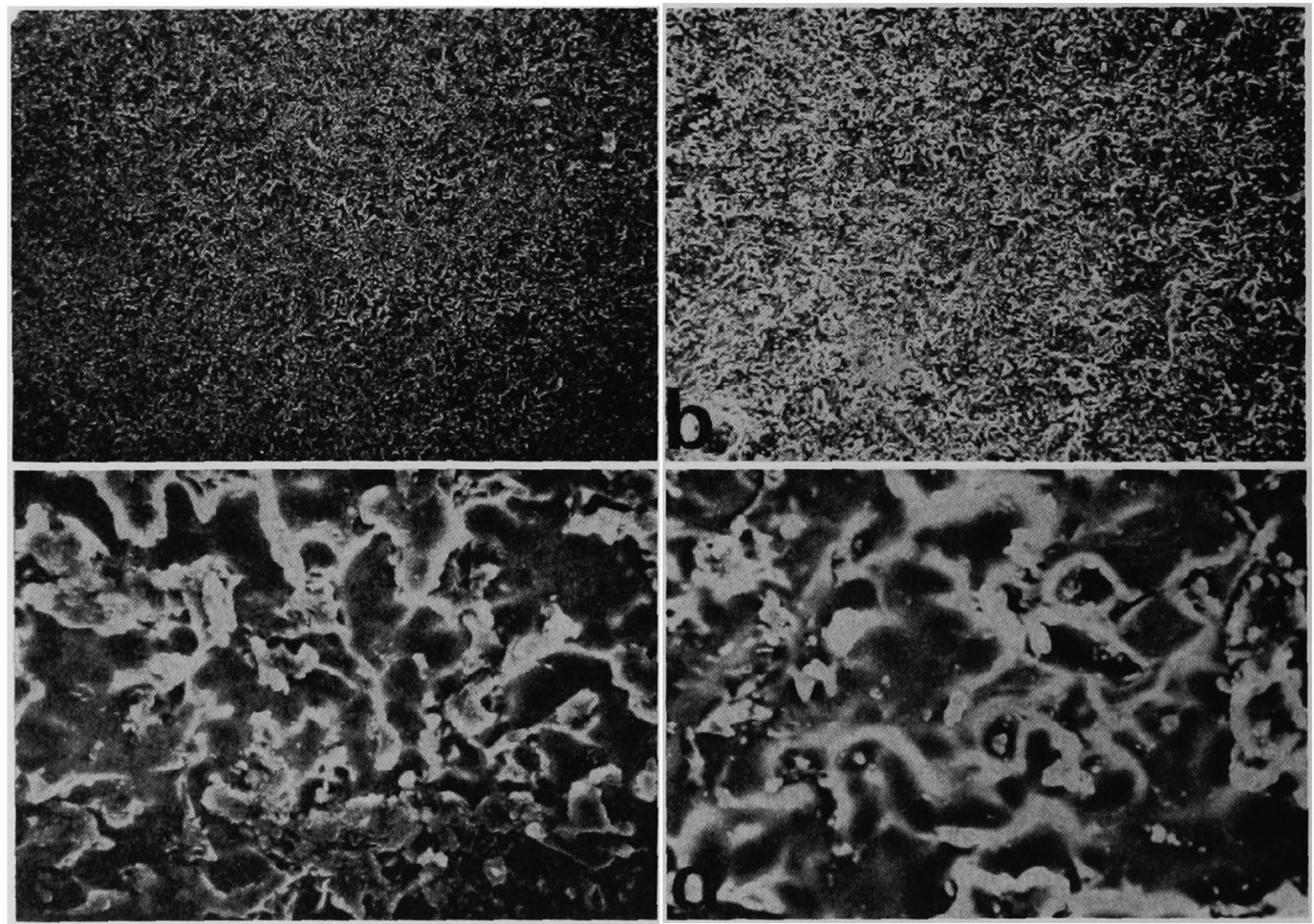

图 13 䉓解研磨 1 分間処理後の走査型電顕写真像 (大型サンドブラスト処理)

a : 対照群 $(\times 100) \quad$ b : 実験群 $(\times 100) \quad c$ : 対照群 $(\times 1,000) \quad d:$ 実験群 $(\times 1,000)$ 


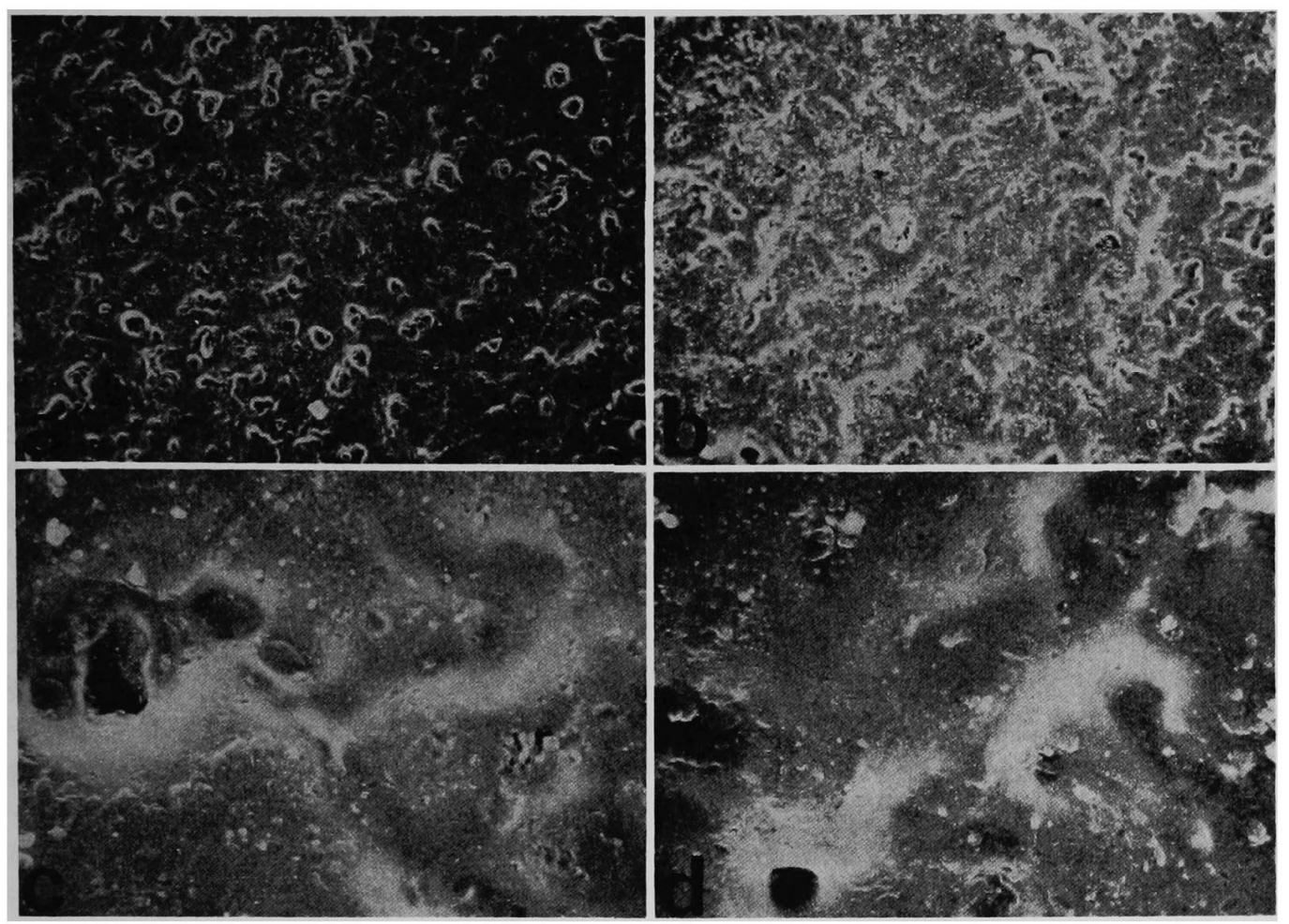

图 14 電解研磨 3 分間処理後の走查型電顕写真像（小型サンドブラスト処理）

$\mathrm{a}$ : 対照群 $(\times 100) \quad \mathrm{b}$ : 実験群 $(\times 100) \quad \mathrm{c}$ : 対照群 $(\times 1,000) \quad \mathrm{d}:$ 実験群 $(\times 1,000)$

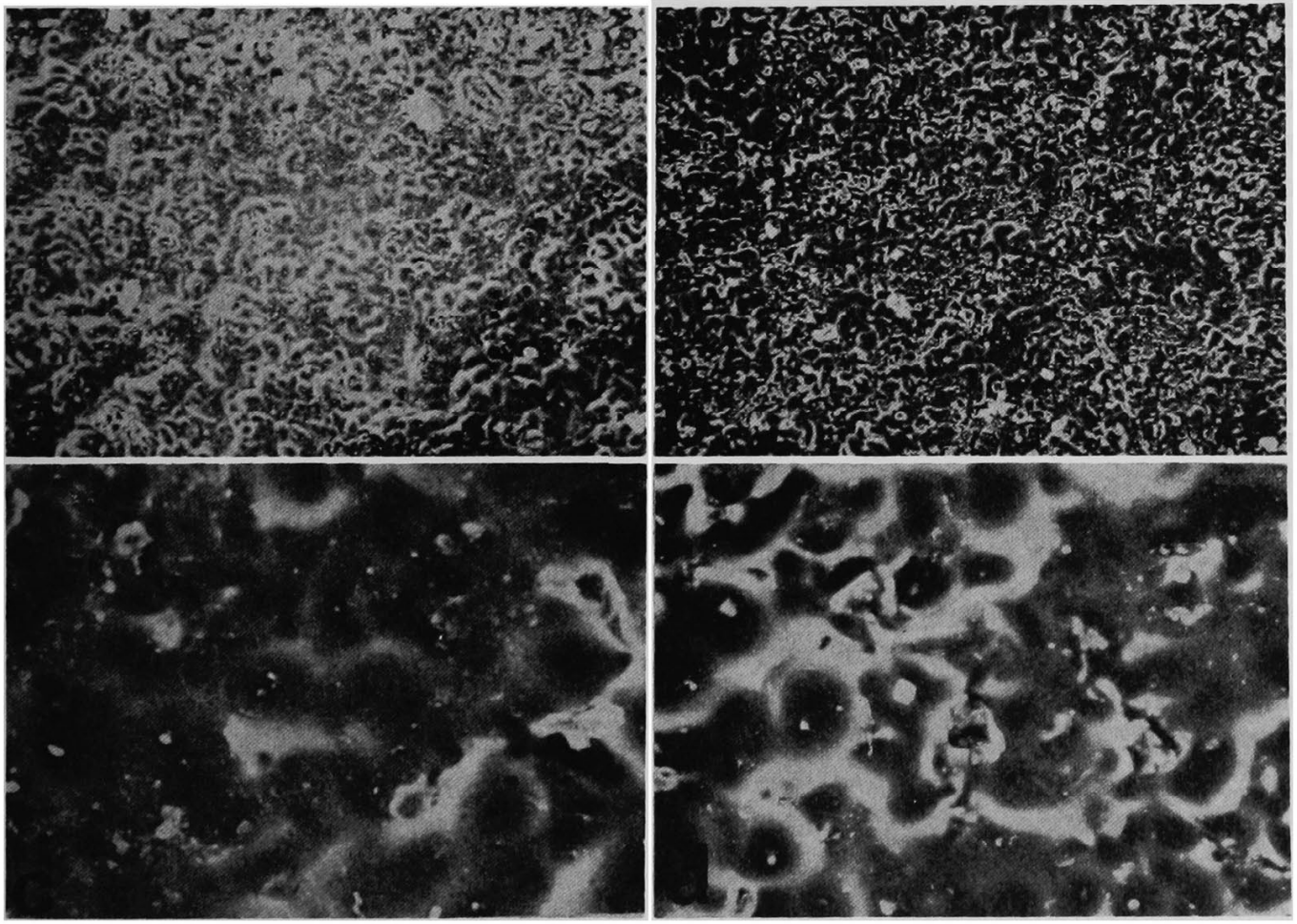

図 15 電解研磨 3 分問処理後の走查型電顕写真像 (大型サンドブラスト処理)

a : 対照群 $(\times 100) \quad$ b : 実験群 $(\times 100) \quad c$ : 対照群 $(\times 1,000) \quad d:$ 実験群 $(\times 1,000)$ 
実験群（図 11-b）ともに細系状の像を呈しているが， 対照群の方がやや均翼な像が見られた．また，1,000 倍 扡大像では, 対照群 (図 11-c) より実験群 (図 11-d) の方が大きな凹部が認められた。

サンドブラスト処理後, さらに電解研磨を 1 分間行っ た試料の走查型電子顕微鏡写真は図 12,13 に示したと おり, 各処理方法でやや異なる像を呈した. 小型サンド ブラスト処理後に電解研磨を行った試料の対照群（図 12-a，c）では表面の凹凸が最も少なかったが, 実験群 （図 12-b，d）ではその周囲が平坦で凹部が非常に深い 像がみられた。一方, 大型サンドブラスト処理後に電 解研磨を行った試料の対照群（図 13-a，c）と実験群 （図 13-b，d）との間には著明な差は認められなかっ た. また, サンドブラスト処理後と電解研磨 1 分間処理 後の写真像を比較すると, 前者では, 各粒子の辺縁が鋸 歯状であるのに対し, 後者では, 丸味を帯びた像が認め られた。

さらに, 電解研磨を 3 分間行った試料の走査型電子顕 微鏡写真は図 14，15 に示すとおりである. いずれの搪 大写真においても表面の凹凸を比較することは困難であ るが，小型サンドブラスト処理後に電解研磨を行った試 料の対照群（図 14-a，c）と実験群（図 14-b，d）で は類円形の小孔が散在しており，大型サンドブラスト処 理後に電解研磨を行った試料の対照群（図 15-a，c） と実験群（図 15-b，d）では鱗状の像を呈した. また， 粒子の辺縁は，いずれの試料においてもさらに丸味を帯 びていることが観察された.

\section{考察}

臨床においてコバルト・クロム合金の鋳造床を製作す る際に主として用いられているリン酸塩系埋没材は, 他 の高温鈜造用埋没材と比べて操作性, 保存性, 耐熱性な どの点で優れているが1 3), 反面, 融解したコバルト・ クロム合金と反応して鋳造体表面を粗粘にするともいわ れている4,5).

一般に鋳造体の表面あらさに影響を及ぼす要因として は, 石管, 印象材, 埋没材などの種類ならびにそれぞれ の操作条件, それにスプルーの太さおよび植立方向など の埋没条件, さらに鋳造リングの加熱速度や係留時間, 鉡型温度, 鋳込温度, 金属の種類, 鋳造方法などの鋳造 条件, ならびに鋳造体の洗浄方法などがあげられる.し かし, 熔融温度が $1,300 \sim 1,500^{\circ} \mathrm{C}$ と高い高熔合金は $1,000^{\circ} \mathrm{C}$ 前後の中熔合金の場合と比較して, 主に次のよ
うな点で異なっている.

まず，複模型を製作する場合，主として寒天印象材と リン酸塩系埋没材が使用されており，そのリン酸塩系埋 没材が寒天印象材中で硬化する際, 寒天印象材中の水分 が埋没材模型の表面性状に影響を与えることが考えられ る ${ }^{15)}$. 次に鋳込まれた高熔合金と埋没材との焼着によっ て鋳造体表面に肌荒れが生じる.これに関して,福井(5)は 鋳型温度が高いほど埋没材中の遊離の $\mathrm{MgO}$ と合金中の クロム酸化物である $\mathrm{Cr}_{2} \mathrm{O}_{3}$ との反応が促進され，化学 的焼着物 Picrochromite s.s. の生成が促進されると報 告している. また, この Picrochromite s.s. の生成は 鋳造時の酸素圧に影響され，真空融解および鋳造によっ て減少するが，高真空下での融解は合金成分の蒸発が問 題となり，このような欠点のないアルゴン，ヘリウムな どの不活性ガス雲用気下にて鋳造操作を行うことを最良 としている．したがって本実験では，金属の融解がすべ てアルゴン雲囲気下で行えるアルゴンアーク加圧鋳造機 （松風社製、アルゴンキャスタ一）を使用して鋳造を行 った. また，高熔合金の場合，前述のように埋没材の粒 子や酸化膜などの焼着が著しいため，鋳造体表面を正確 に観察するためには, 各試料に対する十分な清掃は重要 な操作である.これについて野手" は, ニッケル・クロ 厶合金を使用して $50 \% \mathrm{NaOH}$ 溶液中で 30 分間沸騰さ せる方法が，鋳造体を腐食せず付着した埋没材および酸 化膜を除去するのに最適であると報告しており，本実験 でもこの方法に準じて鋳造体の清掃を十分に行った.

さらに，臨床では鋳造後，サンドブラスト処理および 電解研磨処理が行われている. 本実験では, 鋳造床のよ うな大きな補緅物の研磨に主として使用されている大型 のサンドブラストと, クラウンなどの研磨に使用されて いる小型のサンドブラストとについて比較検討した. さ らに電解研磨については, 研磨液の温度を $15 \sim 30^{\circ} \mathrm{C}$ の 籁囲内とし, 研磨処理に要する時間などが鋳造体の表面 あらさに及ぼす影響と，それぞれの処理による鋳造体の 厚さの変化について検討した.

次に，表面あらさの測定や表面性状の観察に対しては 従来の実験方法と同様に，本実験においても各処理後に おいて, 触針式あらさ測定機を用いて中心線平均あらさ $\left(R_{a}\right)$ と最大あらさ $\left(R_{\max }\right)$ を测定し, 同時に走査型電 子顕微鏡を用いて 100 倍と 1,000 倍に拉大した写真像か ら各試料における表面性状の観察を行い, 鋳造体試料の 表面あらさに対する複印象の操作やサンドブラスト処 理, 電解研磨処理などの影響について比較検討した.

本実験において, 鋳造直後における中心線平均あらさ 
と最大あらさについては，ともに実験群の方が対照群よ りも明らかに大きい値を示し, 図 8 の顕微鏡写真の観察 結果と一致した. これは, 寒天印象材による複印象操作 が鋳造体試料表面に大きく影響を及ぼしており，寒天の 離漿がその原因であると考えられる.この点については 大沢ら ${ }^{13)}$ む，石䯩の表面あらさについて検討したところ ガラス板面上で硬化させたときより，金属原型を寒天印 象材で印象し，その印象面上で硬化させたときの方が大 きいと報告している.

また，鋳造直後において鋳造体試料のスプルー近接部 と遠隔部との表面あらさを比較すると，対照群の中心線 平均あらさにおいてのみ有意差が認められ，実験群の中 心線平均あらさおよび最大あらさと対照群の最大あらさ においては，両者の間に有意差は認められなかった。し たがって，本実験のようなスプルーの植立方向では，試 料の表面あらさに対して，スプルーからの距離による影 響よりも印象操作による影響の方が明らかに大きく作用 しているものと考えられる. 一方，鋳造体試料の表面あ らさ曲線を観察すると，すべての試料においてほぼ同程

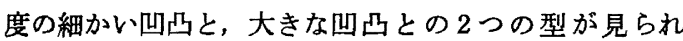
た. 前者は埋没材模型壁のあらさによるもの，後者はコ バルト・クロム合金の凝固時の収縮による陥没と推定さ れ，この凝固収縮による陥没は最大あらさに大きな影響 を及ぼしているものと考えられる．また，鋳造直後の鋳 造体試料のスプルー近接部と遠隔部における最大あらさ について，対照群においてもまた実験群においても有意 差が認められなかったことから、コバルト・クロム合金 の凝固收縮が鋳造体試料の全面にわたって均等に起こっ たものと考えられる. 以上のことから，スプルーからの 位置関係によるちがいが鋳造体試料の表面あらさに及ぼ す影響より，鋳造收縮による影響あるいは寒天印象材に よる複印象の影響の方が大きい勃果をあらわしたものと 考えられる。

これらの試料を小型サンドブラストで1 分間処理する と，対照群および実験群ともにスプルー近接部と遠隔部 との間における表面あらさの有意差はなくなり，また， 鋳造直後に比べて中心線平均あらさおよび最大あらさは ともに小さくなった. このことは, 電子顕微鏡写真の図 8-a，b および図 9-a，b からも明らかなように，サ ンドブラスト処理後の方が細かい像を呈していたことか らもわかる. 一方, 鋳造体試料の厚さは対照群および実 験群でともに約 $2 \mu$ 減少した. なお本実験において, 最 大あらさの減少量の方が厚さの減少量よりわずかに大き くなったが，これは最大あらさおよび厚さの計測部位を
各試料で同一にできなかったためと考えられる.

さらに，小型サンドブラスト処理 3 分後の表面あらさ においては，同じ 1 分後のときに比べてわずかに小さく なる傾向を示した，走査型電子顕微鏡による観察結果か ら検討寸ると，図 10-a，b における板状構造が図 9a ，bよりはっきりしており，これをさらに 1,000 倍の 桩大で観察すると, 図 10-c，d では対照群も実験群も ほぼ同じ大きさの粒子が見られ，図 9- c，d よりも凹 凸の程度が小さくなっていることからも明らかである. 一方, 厚さの娍少量は, さらに追加した 2 分間で約 $4 \mu$, 約 $3 \mu$ となり, 鋳造直後から小型サンドブラスト処理 1 分後までの間の減少量より，単位時間あたりに換算した ときの減少量はやや小さくなる傾向を示した. これは, 表面の凸部が研磨されやすく，研磨がすすむにつれて凸 部の鋭角的なものより鈍角的なものの占める面積が増加 し，試料を同量の厚さだけ減少させるのに要する時間が 増加したものと考えられる。

大型サンドブラスト処理後では, 対照群および実験群 の厚さの減少がそれぞれ約 $11 \mu$, 約 $12 \mu$ であり，また 両者の最大あらさの変化量は約 $4 \mu$, 約 $6 \mu$ であった. したがって，大型サンドブラストの 15 秒間処理により 鋳造体試料の表面が一層削られて新しい面があらわれ， その面のあらさが測定されたものと考えられる.すなわ ち，鋳造面といらより“サンドブラスト処理面”とな り，サンドブラスト処理を行う条件に影響されるものと 考えられる. 走查型電子顕微鏡による観察結果でも，鋳 造直後の像（図 8-a，b）と，大型サンドブラスト処理 後の像（図 11-a，b）との間には明らかにちがいが認 められたことからもわかる. 寸なわち，前者は舗石状で 凹部が認められたのに対し，後者は細系状で凹部はほと んどみられなかった.これは鋳造直後の広くかつ起伏の 大きい台地状部と考えられる部分が，サンドブラスト処 理によってほほ平坦な状態にまで削除され，細かくかっ 小さな起伏の台地状部となり，その台地状部の境界が白 く細系状に観察されたものと考えられる. 大型サンドブ ラスト処理後の 100 倍抗大像での観察の結果, 図 9- $a$, b (小型サンドブラスト処理 1 分後) の細系状の像と類 似しており，また，図 10-a，b（小型サンドブラスト 処理 3 分後) にも細糸状の像が認められ，試料の表面性 状はいずれのサンドブラスト処理においてもほぼ同様の 結果となることがわかった.

さらに，大型サンドブラスト処理による表面あらさは 小型サンドブラスト処理よりも複印象による影響がきわ めて小さくなり，よりサンドブラスト処理効果が強いこ 
$100-788$

とが考えられる.このことは，前者に扔ける試料の厚さ の減少量が後者と比較して 2 3 倍となったことからも 裏付けられる.これは，今回使用した 2 種のサンドブラ ストにおける処理条件の差異によるものと考えられる.

次に, 電解研磨処理を 1 分間行った場合, 走查型電子 顕微鏡による観察結果では各粒子の辺縁が丸味を帯びて きたが，これはサンドブラスト処理後の細系状の像とは 異なるものであった．また，表面あらさについて比較す ると，いずれの試料においても電解研磨 1 分後では， サ ンドブラスト処理後の値との間に有意差はなく，表面あ らさはほとんど変化しなかったが，試料の厚さについて は 3 4 $\mu$ の減少がみられた. また, 走查型電子顕微鏡 で観察されたように各粒子が丸味を帯びた像について は，本実験で用いた触針式あらさ測定機では測定できな いような表面の小さな性状変化（光沢化）であると考え られる. 電解研磨の効果とくにこの光沢化を判定する場 合より高精度の触針式あらさ測定機を使用したり，そ の他の測定方法を併用する必要があるものと考えられ る.

次に電解研磨を計 3 分間行った場合，小型サンドブラ スト処理した試料の中心線平均あらさを比較すると，対 照群および実験群ともに約 $0.3 \mu$ とわずかに小さくなる 傾向を示したが, 電解研磨における厚さの減少量は両者 ともに計 $6 \mu$ となり, 試料表面の凹凸の変化より厚さの 減少量の方が大きくなっていた，一方，大型サンドブラ スト処理した試料においても，対照群ならびに実験群に おける表面あらさは電解研磨によってはほとんど差が認 められず，厚さのみが対照群で計 $6 \mu$, 実験群で計 $8 \mu$ 減少しており，小型サンドブラスト処理の場合と同様に 試料表面の凹凸の変化より厚さの減少量の方が大きくな っていた. 次に図 6 および図 7 に示したように，1 分間 電解研磨を行った場合と, さらに 2 分間電解研磨を追加 した場合とにおいて，各試料群の厚さの減少量が等しい ことから, 単位時間での厚さの減少量は 2 分追加の場合 の方が少なかった.この理由としては，試料表面の凸部 から順次電解研磨され，鋭角的な凸部が鈍角的な凸部人 と変わり,それにつれて研磿される凸部の面積が増加し， 同じ厚さだけ減少するのにより多くの電解研磨時間を要 したものと考えられる.なお本実験では電解研磨を同一 試料で 1 分間と 2 分間とに分けて行っており, 連続して 3 分間行った場合については不明である. 電解研磨を計 3 分間行った試料を走查型電子顕微鏡により観察した結 果では, 電解研磨により各粒子の辺縁が丸味を带びた像 が認められた．大谷 ${ }^{14)} は ，$ 金属を陽極として特殊な電解
液のなかで電解すると, 表面が溶解するにつれて平滑化 と光沢化が起こって研磨面が得られると述べている. 本 実験においても，走查型電子顕微鏡による観察結果から 明らかに光沢現象の現われたことが考えられる. また, 電解研磨後とサンドブラスト処理後との試料表面の走查 型電子顕微鏡による観察結果では，両者が明らかに異な る像を呈していることがわかった。

本実験では，2機種のサンドブラストおよび処理時間 について検討したが，コバルト・クロム合金の表面あら さや試料の厚さに影響を与えると考えられる要因は，既 に述べたように数多く存在し，また電解研磨による表面 あらさの変化についてはその測定方法について考慮する 必要があり, 今後これらの問題について詳細に検討して いくつもりである.

\section{総括および結論}

本研究は，コバルト・クロム合金鋳造床の粘膜面や鋳 造鉤の内面に相当する鋳造体表面のあらさが，サンドブ ラストおよび電解研磨処理によって，どのように変化す るかを検討するために行ったものである。すなわち，ガ ラス面に注型して得た埋没材模型による鋳造体試料を対 照群とし，ガラス面を複印象して得た模型上で製作した 鋳造体試料を実験群として, これら試料表面の中心線平 均あらさおよび最大あらさを測定し，さらに走查型電子 顕微鏡により表面性状を観察した. そこで，これらの処 理によって鋳造体試料の厚さがどのように変化するかを 検討した結果, 次のような結論を得た.

1）鋳造体試料の表面あらさは，スプルー近接部と遠 隔部におけるちがいよりも，鋳造収縮や寒天印象材によ る複印象などの影響の方が明らかに大きかった。

2）小型サンドブラスト処理に扰いては, 対照群, 実 験群ともにスプルー近接部と遠隔部との部位による表面 あらさの差は見られなくなった，一方，対照群と実験群 との間に掞いては明らかに差はみられ，依然として複印 象による影響がみられた，また，研磨時間を長くした場 合, 単位時閒に㧍ける厚さの減少量はやや小さくなる傾 向を示したが，表面あらさに対してはほとんど変化は認 められなかった。

3）大型サンドブラスト処理において，複印象による 影響が，鋳造操作や小型サンドブラスト処理に比較して 明らかに小さくなった. しかし, 試料の厚さについては 小型サンドブラスト処理の $2 \sim 3$ 倍の減少量を示したこ とから,サンドブラストの機種あるいは処理条件によっ 
て鋳造体試料の表面性状が異なることが明らかとなっ た.

4）電解研磨にお゙いて，複印象の影響はわずかに認め られるが，その影響は各サンドブラスト処理よりもやや 小さくなる傾向を示した. また，小型サンドブラスト処 理後の電解研磨により表面あらさはわずかに小さくなっ たが, 大型サンドブラスト処理後の電解研磨においては ほとんど変化がみられなかった，一方，単位時間におけ る厚さの減少量は, 時間の経過に伴って小さくなる傾向 にあり，試料表面における各粒子の辺縁が徐々に丸味を 带び,これが表面の光沢に関与していることが明らかと なった。

稿を終えるに臨み, 本研究に際し, 終始御便宜と御協力を睗 わった昭和歯研株式会社社長森田一人氏ほか従業員各位に厚く 御礼申し上げます.

\section{文献}

1）三浦維四，川上道夫，林 一郎，塩川延洋共訳：スキン ナ一科材料学, 493〜 505, 医霜出版株式会社, 東京, 昭和44.

2）中村健吾，仲居 明：鋳造用コバルト・クロム合金につ いて, 界展望, 47:40４8, 昭51（1976）.

3）東 節男，山賀险一編：最新歯科材料学，156～159, 学 建甾院, 東京, 昭和53.

4) Allan, F. C. and Asgar, K. : Reaction of Cobalt-
Chromium Casting Alloy with Investment, J. Dent. Res., $45: 1516 \sim 1528,1966$

5）福井寿男：鋳造用コハルトークロム合金とリン酸塩系 鋳型材との界面反応物に関寸る研究，愛院大誌，12： $31 \sim 51$, 昭49 (1974).

6）小貫伸一：齿科補緅物の仕上加工に関する研究一齿科 用金属の仕上加工一, 補緅誌, 12(2): 215 239, 昭 43 (1968).

7）奥田礼一：鋳型温の鋳造体面アラサに及ぼす影皘，口病 誌, 35(3)：465〜 477, 昭43 (1968).

8）、林弘之：アルゴンアーク鋳造機による宷科用ニッケ ルクロム合金の鋳造について，第一報 鋳造体の表面粗 さ, 口病誌, 44(4):293 302, 昭52 (1977).

9）野手久史：歯科用ニッケルクロム合金の埋没法と鋳造 体の表面フラサについて，口病誌，40(4)：316〜337, 昭 48 (1973).

10）佐野敬一，野首孝祠，奥野善彦：型ごと埋没法による鋳 造体の表面あらさについて，補緅誌，19：627～631, 昭 51 (1976).

11）山根通裕：各種鋳造機による金合金鋳造体の面アラサ， 材器誌, $23: 23 \sim 28$, 昭45 (1970).

12）森淑子, 稲井 徹, 久保光弘, 自見 忠: 歯科錈造体 の表面あらさに関する研究, 第 1 報 鉡造体の清掃効果 について, 補緅誌, 15:107〜116, 昭46 (1971).

13）大沢 諴, 近藤豊一, 石岡 䇌: 寒天印象材に関する研 究, 第 3 報 寒天印象材による石高表面への影䈏につい $\tau$, 補矧誌，19(2)：266～276，昭50（1975）

14）大谷南海男：金属表面加工理論, 金属表面工業全書 2 , 167, 㮌書店，東京，昭和 43 . 